\title{
KAJIAN POTENSI PEDAGANG KAKI LIMA (PKL) KULINER DALAM PENGEMBANGAN PARIWISATA DI MUARA BUNGO
}

\author{
Yudhi Novriansyah \\ Program Studi Manajemen, Fakultas Ekonomi, Universitas Muara Bungo \\ Jl. Diponegoro No.27 Kelurahan Cadika, Kecamatan Rimbo Tengah, Kabupaten \\ Bungo, Provinsi Jambi, Indonesia 37214. Email: yudhinovriansyah@ yahoo.com
}

\begin{abstract}
The objectives to be achieved in this study are (1). To know the characteristics of tourist visitors to the culinary in Muara Bungo (2). To know and study the region's Culinary through the mapping in Muara Bungo, (3). To know the potential that needs to be improved in Muara Bungo Culinary. Quantitative descriptive research survey approach. Respondents as many as 300 people, this research uses the sample withdrawal Convenience sampling/accidental sampling. The results showed: (1) the characteristics of the majority of visitors are the tourists of young children 21-30 years i.e. 55.3\% where the dominance of male visitors $68.3 \%$, and level of education Equal SLTA $57.3 \%$, private sector job domination 59.7\%, average earnings over 2 million dollars amounted to $42.7 \%$. As for the origin of tourists in general around the mouth of the Bungo $55.7 \%$ or local tourists. Obtain information from the Culinary a 30\% friends and visiting the site with your friends/family 90.7\%; (2) the area's favorite Culinary tourists visit PKL is Pusparagam/Semagor field i.e. $37.3 \%$ and tourist favorite foods are Meatballs $158 \%$, and the Miso favorite drink juices $74 \%$ and Crispy Banana snack 42.7\%; (3) the main reason tourists visit due to the price of $27.7 \%$. Potential needs to be improved is the Culinary and infrastructure improvements, namely $61 \%$ to give convenience to tourists. It is recommended to the Government to increase the potential of Bungo in 5 main areas of Culinary with revamping the facility/infrastructure that is $93 \%$.
\end{abstract}

Keywords: Culinary, Tourism, Muara Bungo

\section{PENDAHULUAN}

Pariwisata merupakan salah satu sektor penting karena perannya sebagai sumber pendapatan daerah juga menjadi sarana branding bagi suatu negara. Salah satu bentuk dari wisata minat khusus adalah wisata kuliner. Wisata kuliner sebenarnya merupakan bagian dari wisata budaya yang berarti wisata ini memiliki nilai tersendiri di mata para wisatawan. Peran vital dari makanan tidak hanya untuk bertahan hidup melainkan juga menyediakan basis industri kreatif. Bidang kuliner saat ini erat kaitannya dengan pariwisata berkelanjutan (sustainable tourism). Bila dicermati lebih lanjut, pelaku usaha kuliner ini pada umumnya adalah Pedagang Kaki Lima disingkat PKL.

PKL sebagai bagian sektor informal seperti yang kita amati belum menjadi prioritas pemerintah. Meskipun pada satu sisi, usaha PKL ini memiliki kekuatan secara sosial ekonomi, diantaranya; pertama, bergerak dari banyak keterbatasan baik sumber daya modal maupun sumber daya manusia, Kedua, keunikan tempat yang ditawarkan oleh PKL berkembangan menjadi sarana atau media interaksi antar masyarakat ditiap lapis golongan. Ketiga, pelayanan yang mengangkat konsep kesetaraan (equality) atau kesamaan pelayanan pada tiap konsumen menjadi kekuatan utama bagi bisnis ini. 
Wisata kuliner saat ini tidak lagi hanya sebatas produk pemuas kebutuhan dasar manusia. Ada unsur rekreasional (tourism) dan petualangan (adventurer), kuliner yang memiliki unsur budaya asli suatu daerah dapat menjadi daya tarik bagi wisatawan untuk datang mengunjungi daerah tersebut. Sementara itu, Kabupaten Bungo sebagai daerah dengan perkembangan ekonomi paling pesat setelah Kota Jambi sebagai Ibukota Provinsi Jambi, banyak pula terdapat pelaku usaha PKL Kuliner. Persebaran pelaku PKL Kuliner di 2 (dua) kawasan utama perdagangan, yaitu Pasar Atas dan Pasar Bawah.

\section{Tinjauan Pustaka}

\section{Pedagang Kaki Lima}

PKL adalah orang yang dengan modal yang relatif sedikit berusaha bidang produksi dan penjualan barang barang (jasa-jasa) untuk memenuhi kebutuhan kelompok tertentu di dalam masyarakat. PKL adalah suatu pekerjaan yang paling nyata dan paling penting di kebanyakan kota di negara-negara berkembang pada umumnya. PKL pada umumnya adalah self-employed, artinya mayoritas PKL hanya terdiri dari satu tenaga kerja. Modal yang dimiliki relatif tidak terlalu besar, dan terbagi atas modal tetap, berupa peralatan, dan modal kerja Dalam pengertian lain, PKL adalah istilah untuk menyebut penjaja dagangan yang menggunakan gerobak. Istilah itu sering ditafsirkan demikian karena jumlah kaki pedagangnya ada lima. Lima kaki tersebut adalah dua kaki pedagang ditambah tiga "kaki" gerobak (yang sebenarnya adalah tiga roda atau dua roda dan satu kaki).

\section{Pengertian Kuliner}

Istilah kuliner di Indonesia dapat dikatakan baru terdengar gaungnya sejak tahun 2005 berkat "Wisata Kuliner", sebuah tayangan televisi yang meliput tempat-tempat makan unik atau sudah memiliki reputasi yang baik. Secara bahasa, kuliner diserap dari bahasa Inggris: Culinary yang memiliki arti sebagai sesuatu yang digunakan dalam memasak atau berkaitan dengan memasak. Dalam praktiknya dikenal istilah Culinary Arts, yaitu teknik dalam menyiapkan makanan sehingga siap dihidangkan. Bila ditinjau dari sisi ekonomi kreatif, belum banyak kajian yang memasukkan kuliner ke dalam sektor ini, karena pada dasarnya makanan merupakan kebutuhan dasar manusia yang sudah ada sejak lama. Produk kuliner pada umumnya masih masuk ke dalam sektor industri makanan dan minuman ataupun industri penyediaannya, tanpa adanya penekanan bahwa produk kuliner merupakan produk kreatif.

Dari penjelasan di atas dapat ditarik suatu definisi umum dari subsektor kuliner pada ekonomi kreatif Indonesia, yaitu: Kegiatan persiapan, pengolahan dan penyajian produk makanan dan minuman yang menjadi unsur kreativitas, estetika, tradisi dan atau kearifan lokal. Sebagai elemen terpenting dalam meningkatkan cita rasa dan nilai produk tersebut, untuk menarik daya beli dan memberikan pengalaman kepada konsumen.

Definisi di atas terdapat beberapa kata kunci, yaitu kreativitas, estetika, tradisi, dan kearifan lokal yang dijelaskan sebagai berikut:

1. Kreativitas. Kreativitas yang dimaksud adalah aspek ide baru yang dapat memberikan nilai tambah.

2. Estetika. Estetika yang dimaksud adalah aspek tampilan dari sebuah makanan dan minuman yang ditata dengan memperhatikan unsur keindahan. 
3. Tradisi. Tradisi yang dimaksud adalah sesuatu yang telah dilakukan sejak lama dan menjadi bagian dari kehidupan suatu kelompok masyarakat

4. Kearifan Lokal. Kearifan lokal yang dimaksud adalah identitas suatu daerah berupa kebenaran yang telah tertanam dalam suatu daerah.

\section{Pariwisata}

Pariwisata menurut Cooper et all (1996) adalah the temporary movement todestination outside the normal home and workplace, the activities undertaken during the stay and the facilities created to cater for the needs of tourist. Menurut UU No 9 tahun 1990 pasal 1 ; pariwisata adalah segala sesuatu yang berhubungan dengan wisata, termasuk pengusahaan ojek dan daya tarik wisata serta usahausaha yang terkait dibidang tersebut. Ada empat dimensi pariwisata ( Mill, 1990) yaitu; Pertama, atraksi yang menjadi faktor pendorong wisatawan untuk pergi mengunjungi destinasi. Kedua, fasilitas yang merupakan jasa pelayanan terhadap para wisatawan. Ketiga, transportasi dan keempat, infrastruktur yang memadai yang menjadi pendukung penyelenggaraan pariwisata.

Ditinjau dari segi etimologi, pariwisata berasal dari kata Sanskerta yaitu Pari dan Wisata. Pari berarti banyak, berkali-kali, berputar-putar serta cukup. Sedangkan Wisata berarti perjalanan, bepergian atau traveling dalam bahasa Inggris. Dengan demikian maka kata Pariwisata diartikan sebagai perjalanan yang dilakukan berkali-kali atau berputar-putar di suatu tempat ke tempat lainnya atau "tour" dalam bahasa Inggris. Sedangkan Tourist (wisatawan).

\section{METODE}

Metode dapat diartikan sebagai cara mendekati, cara mengamati, dan menjelaskan suatu gejala dengan menggunakan landasan teori (Silalahi, 2012: 12). Desain penelitian ini bersifat Deskriptif, yaitu mengkaji sesuatu seperti apa adanya baik variabel tunggal maupun pola hubungan korelasional antara dua atau lebih variabel. Pengumpulan data menggunakan metode Survei, yang menggunakan kuesioner sebagai instrumen utama untuk pengumpulan data (Irawan, 2006). Analisis ini menggunakan pemahaman kuantitatif yang mana pengolahan data ini dalam bentuk angka (scoring) (Sugiyono, 2010:11). Penelitian ini dilakukan dengan pengambilan data di lokasi pelaku PKL Kuliner yang berada di pusat kota Muara Bungo yang secara area terbagi dua kawasan utama, yaitu Pasar Atas dan Pasar Bawah.

\section{Populasi dan Sampel}

a. Populasi : Populasi disebut juga universum, universe, dan universe of discource. Populasi dapat berupa organisme, orang atau sekelompok orang, masyarakat, organisasi, benda, objek, peristiwa, (Herdiansyah, 2010:17). Populasi dalam penelitian ini adalah seluruh wisatawan yang mengunjungi PKL Kuliner di kawasan Pasar Muara Bungo

b. Sampel : Sampel merupakan individu/kelompok Wisatawan yang terkait dengan populasi penelitian (Silalahi, 2012:253). Ukuran sampel yang layak dalam penelitian adalah antara $30 \mathrm{~s} / \mathrm{d} 500$ (Sugiyono, 2010:97). Adapun sampel penelitian ini sebanyak 300 orang. Proses penarikan sampel penelitian menggunakan metode Convenience Sampling/Accidental Sampling, yaitu pemilihan sampel dari siapa saja yang kebetulan ada atau dijumpai dilokasi penelitian (Silalahi, 2012:272). 


\section{Teknik Pengumpulan Data}

a. Kuesioner (Angket) yaitu berupa pengumpulan data yang dilakukan dengan cara memberikan beberapa pertanyaan atau peryataan tertulis kepada responden untuk diisi.

b. Observasi yaitu metode pengumpulan data yang digunakan untuk menghimpun data penelitian dan data tersebut dihimpun dengan cara penggunaan panca indera.

\section{Alat Analisis Data}

Pengukuran dalam penelitian ini merupakan pemberian angka-angka secara nominal terhadap berbagai indikator atau parameter dari seluruh variabel penelitian. Analisa yang digunakan adalah statistik deskriptif tentang karakteristik wisatawan, pemetaan wilayah dan potensi PKL Kuliner di Muara Bungo, dengan menggunakan instrumen SPSS.

\section{HASIL}

Hasil persebaran kuesioner dan analisis menggunakan statistik deskriptif didapatkan hasil sebagai berikut yang dijelaskan di bawah ini:

\section{Tabel 1}

Identitas wisatawan berdasarkan Jenis kelamin

\begin{tabular}{llrrrr}
\hline & & Frequency & Percent & Valid Percent & Cumulative Percent \\
\hline Valid & Laki-Laki & 205 & 68.3 & 68.3 & 68.3 \\
& Perempuan & 95 & 31.7 & 31.7 & 100.0 \\
& Total & 300 & 100.0 & 100.0 & \\
\hline
\end{tabular}

Sumber: olahan data

Pada saat pengambilan data partisipan yang mengisi angket berjumlah 300 orang dari jumlah sampel yang ada. Masyarakat yang mengisi 205 diantaranya berjenis kelamin laki-laki dan sisanya 95 perempuan.

Tabel 2

Identitas Wisatawan berdasarkan Umur

\begin{tabular}{lcrrrr}
\hline & Frequency & Percent & Valid Percent & Cumulative Percent \\
\hline Valid & $<20$ th & 22 & 7.3 & 7.3 & 7.3 \\
& $>40$ th & 38 & 12.7 & 12.7 & 20.0 \\
& $21-30$ th & 166 & 55.3 & 55.3 & 75.3 \\
31-40 th & 74 & 24.7 & 24.7 & 100.0 \\
& Total & 300 & 100.0 & 100.0 & \\
\hline
\end{tabular}

Sumber: olahan data

Tabel 2 diatas berdasarkan umur, dapat terlihat paling dominan dari Wisatawan yaitu sekitar umur 21 - 30 tahun, sedangkan yang paling kecil persentasinya yaitu umur $<20$ tahun yang Wisatawannya hanya 22 orang. 


\section{Tabel 3}

Identitas Wisatawan berdasarkan Pendidikan Terakhir

\begin{tabular}{llrrrr}
\hline & & Frequency & Percent & Valid Percent & Cumulative Percent \\
\hline Valid & Akademi & 25 & 8.3 & 8.3 & 8.3 \\
& P.Tinggi & 81 & 27.0 & 27.0 & 35.3 \\
SD & 3 & 1.0 & 1.0 & 36.3 \\
SLTA & 172 & 57.3 & 57.3 & 93.7 \\
SLTP & 19 & 6.3 & 6.3 & 100.0 \\
Total & 300 & 100.0 & 100.0 & \\
\hline
\end{tabular}

Sumber: olahan data

Berdasarkan Tabel 3 kuesioner diatas dapat ditarik kesimpulan bahwa kebanyakan Wisatawan yang pendidikan terakhirnya adalah SLTA yang mendapatkan persentasi sebanyak 57,33\% yang terdiri dari 172 orang.

\section{Tabel 4}

Identitas Wisatawan berdasarkan Profesi

\begin{tabular}{llrrrr}
\hline & Frequency & Percent & Valid Percent & Cumulative Percent \\
\hline Valid & Mahasiswa & 36 & 12.0 & 12.0 & 12.0 \\
& PNS & 76 & 25.3 & 25.3 & 37.3 \\
Siswa & 9 & 3.0 & 3.0 & 40.3 \\
Swasta & 179 & 59.7 & 59.7 & 100.0 \\
Total & 300 & 100.0 & 100.0 & \\
\hline
\end{tabular}

Sumber: olahan data

Tabel 4 diatas dapat ditari kesimpulan bahwa karyawan swasta mendapatkan persentase paling besar yaitu 59,67\% yang Wisatawannya terdiri dari 179 orang.

Tabel 5

Pemasukan Wisatawan berdasarkan Pendapatan (bulan)

\begin{tabular}{lrrrr}
\hline & Frequency & Percent & Valid Percent & Cumulative Percent \\
\hline$<500000$ & 12 & 4.0 & 4.0 & 4.0 \\
$>2000000$ & 128 & 42.7 & 42.7 & 46.7 \\
1000000 & 39 & 13.0 & 13.0 & 59.7 \\
1500000 & 90 & 30.0 & 30.0 & 89.7 \\
500000 & 31 & 10.3 & 10.3 & 100.0 \\
Total & 300 & 100.0 & 100.0 & \\
\hline
\end{tabular}

Sumber: olahan data

Tabel 5 data diatas, dapat kita lihat hasil perolehan Wisatawan yang pendapatan / bulannya mendapatkan persentasi terbesar adalah Wisatawan yang pendapatannya sebesar $>2.000 .000,00$ yaitu nilai persentasinya $42,7 \%$ dari jumlah Wisatawan. 


\section{Tabel 6}

Pengeluaran Wisatawan berdasarkan (bulan)

\begin{tabular}{rlrrrr}
\hline & Frequency & \multicolumn{1}{c}{ Percent } & Valid Percent & Cumulative Percent \\
\hline Valid & $<500000$ & 40 & 13.3 & 13.3 & 13.3 \\
& $>2000000$ & 42 & 14.0 & 14.0 & 27.3 \\
& 1000000 & 47 & 15.7 & 15.7 & 43.0 \\
1500000 & 54 & 18.0 & 18.0 & 61.0 \\
& 500000 & 117 & 39.0 & 39.0 & 100.0 \\
& Total & 300 & 100.0 & 100.0 & \\
\hline
\end{tabular}

Sumber: olahan data

Tabel 6 di atas menunjukkan bahwa identitas Wisatawan berdasarkan pengeluaran / bulan yang persentasinya tertinggi adalah $39 \%$ yang mana rata-rata pengeluaran sejumlah $\mathrm{Rp} 500.000,00$ - Rp 1.000.000,00 yang jumlah Wisatawannya sebanyak 117 orang dari jumlah sampel.

Tabel 7

Daerah asal Wisatawan pengunjung PKL Kuliner

\begin{tabular}{llrrrr}
\hline & & & \multicolumn{2}{c}{ Cumulative } \\
Valid & Kec di Bungo & 86 & 28.7 & 28.7 & 28.7 \\
& Luar Provinsi & 12 & 4.0 & 4.0 & 32.7 \\
& Sekitar Bungo & 167 & 55.7 & 55.7 & 88.3 \\
& Luar Kota & 35 & 11.7 & 11.7 & 100.0 \\
Bungo & 300 & 100.0 & 100.0 & \\
Total & & & & \\
\hline
\end{tabular}

Sumber: olahan data

Tabel 7 di atas menunjukkan bahwa mayoritas pengunjung PKL Kuliner adalah warga Muara Bungo dalam kota sebesar 55,7 \% dan yang paling sedikit adalah pengunjung luar Provinsi Jambi sebesar 4\%. Dapat diartikan bahwa pengunjung pada umumnya adalah masuk kategori wisatawan lokal.

Tabel 8

Informasi pengunjung PKL Kuliner

\begin{tabular}{lrrrr}
\hline & Frequency & Percent & Valid Percent & Cumulative Percent \\
\hline Valid Dari teman & 90 & 30.0 & 30.0 & 30.0 \\
Dari Media Sosial/Media daring & 65 & 21.7 & 21.7 & 51.7 \\
Dari media massa & 43 & 14.3 & 14.3 & 66.0 \\
Dari keluarga & 68 & 22.7 & 22.7 & 88.7 \\
Dari informasi lainnya & 34 & 11.3 & 11.3 & 100.0 \\
Total & 300 & 100.0 & 100.0 & \\
\hline
\end{tabular}

Sumber: olahan data 
Tabel 8 data diatas, dapat kita lihat hasil perolehan Wisatawan pengunjung PKL Kuliner paling banyak memperoleh informasi dari teman sebesar $30 \%$ sedangkan yang terendah adalah informasi lainnya yang diperoleh Wisatawan sebesar $11,3 \%$.

Tabel 9

Teman kunjungan ke kawasan PKL Kuliner

\begin{tabular}{llrrrr}
\hline & & Frequency & Percent & Valid Percent & Cumulative Percent \\
\hline Valid & Sendiri & 28 & 9.3 & 9.3 & 9.3 \\
& Teman/Keluarga & 272 & 90.7 & 90.7 & 100.0 \\
& Total & 300 & 100.0 & 100.0 & \\
\hline
\end{tabular}

Sumber: olahan data

Tabel 9 hasil survei yang dilakukan peneliti, dapat di lihat pada grafik di atas bahwa pengunjung mayoritas datang bersama keluarga atau teman dengan jumlah $90,7 \%$, sedangkan yang datang sendiri persentasenya sangat kecil hanya berjumlah $9,3 \%$.

Tabel 10

Frekuensi Kunjungan wisatawan ke lokasi PKL Kuliner (dalam sebulan)

\begin{tabular}{llrrrr}
\hline & Frequency & Percent & Valid Percent & Cumulative Percent \\
\hline Valid & $<$ 3kali & 30 & 10.0 & 10.0 & 10.0 \\
& $3-6$ kali & 221 & 73.7 & 73.7 & 83.7 \\
& $>$ 6 kali & 49 & 16.3 & 16.3 & 100.0 \\
Total & 300 & 100.0 & 100.0 & \\
\hline
\end{tabular}

Sumber: olahan data

Tabel 10 di atas dapat dilihat dari jumlah Wisatawan yang telah di survei, kebanyakan rerponden mengunjungi lokasi PKL Kuliner di Muara Bungo 3-6 kali per bulan dengan jumlah $73,7 \%$ sedangkan yang paling sedikit adalah berkunjung lebih dari 6 kali sebulan sebesar $10 \%$ saja.

Tabel 11

Makanan favorit pilihan wisatawan dilokasi PKL Kuliner

\begin{tabular}{llrrrr}
\hline & Frequency & Percent & Valid Percent & Cumulative Percent \\
\hline Valid & Nasi/Mie Goreng & 36 & 12.0 & 12.0 & 12.0 \\
& Pecel Lele & 57 & 19.0 & 19.0 & 31.0 \\
Siomay & 1 & .3 & .3 & 31.3 \\
Sate & 8 & 2.7 & 2.7 & 34.0 \\
Nasi Ampera & 7 & 2.3 & 2.3 & 36.3 \\
Bakso/Miso & 174 & 58.0 & 58.0 & 94.3 \\
Martabak & 17 & 5.7 & 5.7 & 100.0 \\
India/Mesir & 300 & 100.0 & 100.0 & \\
Total & & & &
\end{tabular}

Sumber: olahan data 
Berdasarkan Tabel 11 di atas dengan persebaran penjual yang relatif banyak, menu favorit wisatawan PKL Kuliner adalah Bakso/Miso sebesar 58\% sedangkan yang terendah adalah siomay hanya $0,3 \%$

Tabel 12

Minuman favorit pilihan wisatawan PKL Kuliner

\begin{tabular}{llrrrr}
\hline & Frequency & Percent & Valid Percent & Cumulative Percent \\
\hline Valid & Aneka Juss & 222 & 74.0 & 74.0 & 74.0 \\
& Es Tebu & 57 & 19.0 & 19.0 & 93.0 \\
& Bandrek/Teh telur & 21 & 7.0 & 7.0 & 100.0 \\
& Total & 300 & 100.0 & 100.0 & \\
\hline
\end{tabular}

Sumber: olahan data

Tabel 12 di atas, bahwa minuman favorit Wisatawan di PKL Kuliner adalah aneka juss sebesar $74 \%$ sedangkan yang terendah adalah minuman kesehatan bandrek/teh telur sebesar $7 \%$.

Tabel 13

Makanan cemilan favorit wisatawan PKL Kuliner

\begin{tabular}{|c|c|c|c|c|c|}
\hline & & Frequency & Percent & Valid Percent & Cumulative Percent \\
\hline \multirow[t]{5}{*}{ Valid } & Aneka gorengan & 86 & 28.7 & 28.7 & 28.7 \\
\hline & Jagung bakar & 54 & 18.0 & 18.0 & 46.7 \\
\hline & Pisang crispy & 128 & 42.7 & 42.7 & 89.3 \\
\hline & Kacang rebus & 32 & 10.7 & 10.7 & 100.0 \\
\hline & Total & 300 & 100.0 & 100.0 & \\
\hline
\end{tabular}

Sumber: olahan data

Tabel 13 di atas, makanan favorit pilihan konsumen PKL Kuliner adalah pisang crispy sebesar $42,7 \%$ dan pilihan terendah adalah cemilan kacang rebus sebesar $10,7 \%$

Tabel 14

Lokasi favorit kunjungan wisatawan PKL Kuliner

\begin{tabular}{llrrrr}
\hline & Frequency & Percent & Valid Percent & Cumulative Percent \\
\hline Valid & Pasar Atas-Mesjid Agung & 10 & 3.3 & 3.3 & 3.3 \\
& Kawasan Toko Panjang & 4 & 1.3 & 1.3 & 4.7 \\
Jl Prof.M. Yamin & 45 & 15.0 & 15.0 & 19.7 \\
Semagor/Pusparagam & 112 & 37.3 & 37.3 & 57.0 \\
Jl Sultan Thaha & 29 & 9.7 & 9.7 & 66.7 \\
Jl Tayib RH & 100 & 33.3 & 33.3 & 100.0 \\
Total & 300 & 100.0 & 100.0 & \\
\hline
\end{tabular}

Sumber: olahan data 
Tabel 14 di atas, pemetaan wilayah berjualan PKL Kuliner yang menjadi favorit kunjungan konsumen adalah di kawasan lapangan Pusparagam atau yang lebih dikenal dengan sebutan lapangan Semagor dengan persentase 37,3\%, di urutan kedua adalah kawasan J1 Tayib RH yang menjadi jalur padat di kota Muara Bungo. Sedangkan pilihan paling sedikit adalah wilayah PKL kuliner kawasan Pertokoan Panjang yang dikenal juga dengan kawasan dagang pecinan/toko pengusaha keturunan Tionghoa sebesar 1,3\% yang dipilih 4 orang Wisatawan.

\section{Tabel 15}

Alasan wisatawan suka berkunjung ke lokasi PKL Kuliner

\begin{tabular}{lrrrr}
\hline & Frequency & Percent & Valid Percent & Cumulative Percent \\
\hline Valid Aksesbilitas/kemudahan mencapai tempat & 74 & 24.7 & 24.7 & 24.7 \\
Amenitas (sarana/prasarana) & 30 & 10.0 & 10.0 & 34.7 \\
Pelayanan & 41 & 13.7 & 13.7 & 48.3 \\
Harga & 83 & 27.7 & 27.7 & 76.0 \\
Kualitas makanan/minuman & 72 & 24.0 & 24.0 & 100.0 \\
Total & 300 & 100.0 & 100.0 & \\
\hline
\end{tabular}

Sumber: olahan data

Tabel 15 di atas, alasan konsumen yang paling dominan berkunjung ke lokasi PKL Kuliner di Muara Bungo adalah harga makanan/minuman sebesar 27,7\%. Sedangkan Amenitas (sarana/prasarana) menjadi pilihan terendah Wisatawan sebesar $10 \%$.

Tabel 16

Hal yang perlu ditingkatkan pelaku usaha PKL Kuliner

\begin{tabular}{llrrrr}
\hline & & Frequency & Percent & Valid Percent & Cumulative Percent \\
\hline Valid & Sarana/Prasarana & 183 & 61.0 & 61.0 & 61.0 \\
& Rasa dan tampilan & 17 & 5.7 & 5.7 & 66.7 \\
& Bersih dan rapi & 100 & 33.3 & 33.3 & 100.0 \\
& Total & 300 & 100.0 & 100.0 & \\
\hline
\end{tabular}

Sumber: olahan data

Tabel 16 di atas, menunjukkan harapan Wisatawan kepada pelaku usaha PKL Kuliner paling dominan adalah perbaikan sarana dan prasarana sebesar $61 \%$. Sedangkan yang paling sedikit dipilih Wisatawan adalah perbaikan rasa dan tampilan sebesar 5,7\%.

Tabel 17

Peran pemerintah daerah mendukung PKL Kuliner

\begin{tabular}{|c|c|c|c|c|c|}
\hline & & Frequency & Percent & Valid Percent & $\begin{array}{c}\text { Cumulative } \\
\text { Percent }\end{array}$ \\
\hline Valid & $\begin{array}{l}\text { Pengembangan } \\
\text { produk dan } \\
\text { kemasan }\end{array}$ & 19 & 6.3 & 6.3 & 6.3 \\
\hline
\end{tabular}




\begin{tabular}{lrrrr} 
Sarana/prasarana & 279 & 93.0 & 93.0 & 99.3 \\
Permodalan & 2 & .7 & .7 & 100.0 \\
Total & 300 & 100.0 & 100.0 & \\
\hline
\end{tabular}

Sumber: olahan data

Tabel $17 \mathrm{di}$ atas, peran Pemerintah Kabupaten Bungo yang paling diharapkan untuk mendukung PKL Kuliner adalah dukungan perbaikan sarana dan prasarana sebesar $93 \%$. Kemudian yang rendah adalah bantuan permodalan $0,7 \%$.

\section{SARAN}

1. Disarankan pelaku usaha PKL Kuliner memperluas promosi lewat jaringan words of mouth (getok tular) dikalangan anak muda yang dominan sebagai wisatawan pengunjung.

2. Disarankan pelaku usaha PKL Kuliner meningkatkan sarana/prasarana fisik yang menarik minat wisatawan dan memberi kenyamanan para pengunjung.

3. Disarankan kepada Pemerintah Kabupaten Bungo menata dan membenahi 5 kawasan utama PKL Kuliner yang ada agar potensi PKL Kuliner sebagai pengembangan pariwisata Muara Bungo lebih optimal dan memberi dampak bagi Pendapatan Asli Daerah (PAD) Sektor Pajak/Retribusi.

\section{DAFTAR PUSTAKA}

Besra, Eri. Potensi wisata kuliner dalam mendukung pariwisata Di kota padang, Fakultas Ekonomi - Universitas Muhammadiyah Sumatera Utara, Vol 12 No. 1 / Maret 2012

Herdiansyah, Haris. Metode Penelitian Kualitatif Untuk Ilmu-Ilmu Sosial, Salemba Humanika: Jakarta, 2010.

Irawan, Prasetya, Penelitian Kualitatif dan Kuantitatif Untuk Ilmu - Ilmu Sosial, Departemen Ilmu Administrasi FISIP UI: Jakarta, 2007

Jumhur, Model Pengembangan Pedagang Kaki Lima (PKL) Kuliner di Kota Singkawang Jurnal Ekonomi Bisnis dan Kewirausahaan 2015, Vol. 4, No. 1, 125-139

Kurniawan, Albert, SPSS Serba Serbi Analisis Statistik dengan Cepat dan Mudah, Jasakom, Jakarta, 2011.

Kementerian Pariwisata Dan Ekonomi Kreatif, Republik Indonesia, 2013, Ekonomi Kreatif, Rencana pengembangan kuliner nasional 2015-2019,

Silalahi, Ulber. Metode Penelitian Sosial, Refika Adhitama: Bandung, 2012

Sugiyono, Metode Penelitian Administrasi dilengkapi dengan Metode R\&D (Bandung: Alfabeta, 2010)

Usman, Husaini dan Purnomo Setiady Akbar, Metodologi penelitian sosial, Bumi Aksara, Jakarta; 2003. 